Maps Showing the Change in Modern Sediment Thickness on the Inner Continental Shelf Offshore of Fire Island, New York, Between 1996-97 and 2011

Open-File Report 2014-1238 



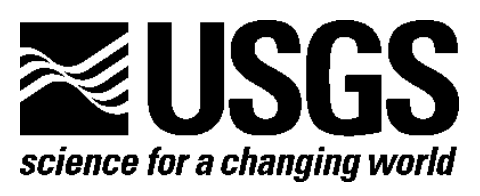

\section{Maps Showing the Change in Modern Sediment Thickness on the Inner Continental Shelf Offshore of Fire Island, New York, Between 1996-97 and 2011}

By William C. Schwab, Wayne E. Baldwin, and Jane F. Denny

Open-File Report 2014-1238

U.S. Department of the Interior

U.S. Geological Survey 


\section{U.S. Department of the Interior \\ SALLY JEWELL, Secretary}

\section{U.S. Geological Survey \\ Suzette M. Kimball, Acting Director}

U.S. Geological Survey, Reston, Virginia: 2014

For more information on the USGS—-the Federal source for science about the Earth,

its natural and living resources, natural hazards, and the environment-visit

http://www.usgs.gov or call 1-888-ASK-USGS

For an overview of USGS information products, including maps, imagery, and publications, visit http://www.usgs.gov/pubprod

To order this and other USGS information products, visit http://store.usgs.gov

Any use of trade, product, or firm names is for descriptive purposes only and does not imply endorsement by the U.S. Government.

Although this information product, for the most part, is in the public domain, it also may contain copyrighted materials as noted in the text. Permission to reproduce copyrighted items must be secured from the copyright owner.

Suggested citation:

Schwab, W.C., Baldwin, W.E., and Denny, J.F., 2014, Maps showing the change in modern sediment thickness on the inner continental shelf offshore of Fire Island, New York, Between 1996-97 and 2011: U.S. Geological Survey Open-File Report 2014-1238, 8 p., http://dx.doi.org/10.3133/ofr20141238.

ISSN 2331-1258 (online) 


\section{Acknowledgments}

We thank the captain and crew of the motor vessel Scarlett Isabella for their skill and cooperation at sea. Brian Johnson, from Coastal Carolina University, and Emile Bergeron, Eric Moore, Charles Worley, and Barry Irwin, all with the U.S. Geological Survey, provided technical support at sea. Andrea Toran was extremely helpful in the publication of this report. We thank Dave Foster and Larry Poppe for their reviews of this manuscript. 


\section{Contents}

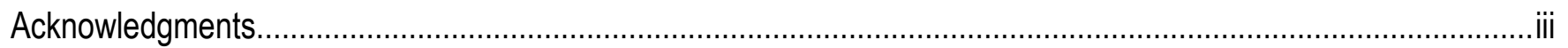

Abstract ………

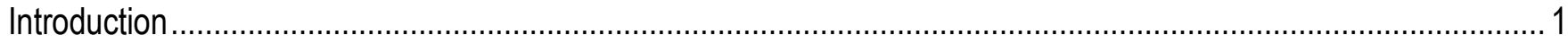

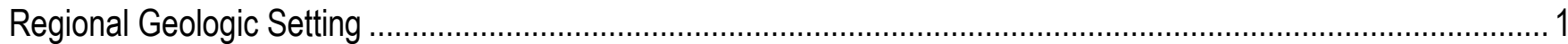

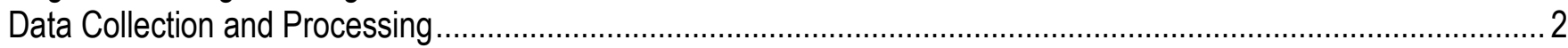

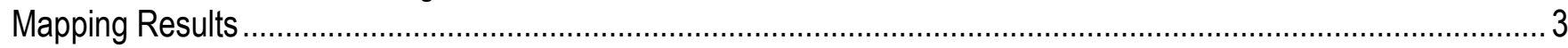

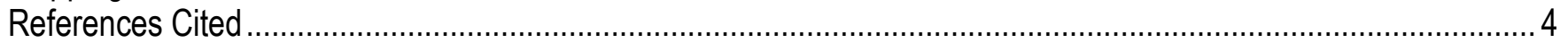

\section{Figures}

1. Map showing the survey area (shaded in dark gray) offshore of Fire Island, New York, 2011..

2. High-resolution chirp seismic-reflection profile and interpretation illustrating stratigraphic features and geometries discussed in the text............................................................................................... 6

3. $A$, Map showing the change in modern sediment thickness greater than 0.5 meter $(\mathrm{m})$ between isopachs interpreted from 1996-97 (Foster and others, 1999) and 2011 (Schwab, Denny, and Baldwin, 2014) seismic-reflection data, overlain on the 2011 modern sediment thickness isopach (Schwab, Denny, and Baldwin, 2014), offshore of Fire Island, New York. Blue line shows seaward extent (toe) of the shoreface (Schwab, Baldwin, Denny, and others, 2014). Regional bathymetric contours are in meters below the North American Vertical Datum of 1988 (NAVD 88). Figure modified from Schwab, Baldwin, Denny, and others (2014). B, Enlargement of area shown in $A$.

4. Maps showing the 1- and 3-meter $(\mathrm{m})$ contours of sediment thickness from the 1996-97 and 2011 surveys offshore of Fire Island, New York, of the $A$, shoreface-attached sand ridges and $B$, area of accretion on the lower shoreface overlain on the 2011 modern sand thickness (Schwab, Denny, and Baldwin, 2014).......... 8 


\section{Conversion Factors}

International System of Units to Inch/Pound

\begin{tabular}{|c|c|c|}
\hline Multiply & By & To obtain \\
\hline \multicolumn{3}{|c|}{ Length } \\
\hline centimeter $(\mathrm{cm})$ & 0.3937 & inch (in.) \\
\hline meter $(\mathrm{m})$ & 3.281 & foot (ft) \\
\hline kilometer (km) & 0.6214 & mile (mi) \\
\hline kilometer (km) & 0.5400 & mile, nautical (nmi) \\
\hline meter $(\mathrm{m})$ & 1.094 & yard (yd) \\
\hline \multicolumn{3}{|c|}{ Area } \\
\hline square kilometer $\left(\mathrm{km}^{2}\right)$ & 247.1 & acre \\
\hline square kilometer $\left(\mathrm{km}^{2}\right)$ & 0.3861 & square mile $\left(\mathrm{mi}^{2}\right)$ \\
\hline \multicolumn{3}{|c|}{ Volume } \\
\hline cubic meter $\left(\mathrm{m}^{3}\right)$ & 35.31 & cubic foot $\left(\mathrm{ft}^{3}\right)$ \\
\hline \multicolumn{3}{|c|}{ Velocity } \\
\hline meter per second $(\mathrm{m} / \mathrm{s})$ & 3.281 & foot per second ( $\mathrm{ft} / \mathrm{s})$ \\
\hline
\end{tabular}

\section{Datum}

Vertical coordinate information is referenced to the North American Vertical Datum of 1988 (NAVD 88).

Horizontal coordinate information is referenced to the World Geodetic System 1984 (WGS 84).

Depth, as used in this report, refers to distance below the vertical datum. 


\title{
Maps Showing the Change in Modern Sediment Thickness on the Inner Continental Shelf Offshore of Fire Island, New York, Between 1996-97 and 2011
}

\author{
By William C. Schwab, Wayne E. Baldwin, and Jane F. Denny
}

\begin{abstract}
The U.S. Geological Survey mapped approximately 336 square kilometers of the lower shoreface and inner continental shelf offshore of Fire Island, New York, in 1996 and 1997, using highresolution sidescan-sonar and seismic-reflection systems, and again in 2011, using interferometric sonar and high-resolution chirp seismic-reflection systems. This report presents a comparison of sediment thickness and distribution as mapped during these two investigations. These spatial data support research on the Quaternary evolution of the Fire Island coastal system and provide baseline information for research on coastal processes along southern Long Island.
\end{abstract}

\section{Introduction}

In 1996 and 1997, the U.S. Geological Survey, in cooperation with the U.S. Army Corps of Engineers, conducted a program to produce geologic framework maps of the nearshore areas south of Long Island, New York (Schwab and others, 1997; Foster and others, 1999; Schwab, Thieler, Allen, and others, 2000). Mapping methods included high-resolution sidescan-sonar and seismic-reflection techniques. The goal of this investigation was to determine regional-scale availability of sand as a resource for future beach nourishment programs and to investigate the role that inner continental shelf morphology and geologic framework have in the evolution of the coastal region of southern Long Island.

In 2011, a high-resolution marine geophysical survey of the lower shoreface and inner continental shelf was conducted offshore of Fire Island, New York (Schwab, Denny, and Baldwin, 2014). This report presents maps of the change in modern sediment thickness and distribution detected between the 1996-97 and 2011 mapping investigations. The results suggest that the nearshore/shoreface sedimentary deposit has gained sediment at the expense of continued erosion of the marine transgressive surface. This report adds to a scientific foundation used to manage coastal systems and assess environmental changes caused by natural processes and human activities.

\section{Regional Geologic Setting}

Long Island marks the southern terminus of the Wisconsinan Laurentide glacial advance in the eastern part of North America (Stone and Borns, 1986). The coast from Southampton to Montauk Point is a headland region where the Ronkonkoma moraine (fig. 1) and associated glacial outwash sediment 
are eroded directly by wave action (Williams, 1976). The south shore of Long Island west of Southampton consists of reworked outwash and includes shallow back-barrier bays, marshes, and lowrelief, sandy barrier islands (Leatherman and Allen, 1985). Located within this barrier-island system is Fire Island, a 0.5 - to 1.0 -kilometer $(\mathrm{km})$-wide, $50-\mathrm{km}$-long barrier island that is bound by two tidal inlets, Moriches Inlet to the east and Fire Island Inlet to the west (fig. 1).

Pleistocene glaciofluvial outwash deposits are exposed over much of the inner continental shelf south of Fire Island. The upper surface of the Pleistocene deposits was incised by a series of paleochannels that were subsequently filled with a transgressive sequence of glaciofluvial sediment, in places capped by lower Holocene muddy estuarine sediment (fig. 2). The modern sand deposit is derived from erosion of these Pleistocene glaciofluvial and lower Holocene fluvial channel-fill deposits exposed on the inner continental shelf by oceanographic processes during the Holocene marine transgression. The distribution of the modern sand deposit is discontinuous and variably thick, and it lies unconformably atop the Pleistocene and lower Holocene deposits (figs. 2 and 3). This unconformity is interpreted to be the Holocene transgressive surface. For a full review of the major inner continental shelf sedimentary sequences offshore of New York, see Schwab, Baldwin, Denny and others (2014) and Schwab, Denny, and Baldwin (2014) and references therein.

\section{Data Collection and Processing}

The area offshore of Fire Island was surveyed by using high-resolution sidescan-sonar, seismicreflection, bathymetric, and sediment-sampling techniques in May 1996 aboard the research vessel Seaward Explorer, and in May 1997 and September to October 1997 aboard the research vessel Diane $G$. Details of the sidescan-sonar and fathometer acquisition and processing are described by Schwab, Thieler, Denny, and others (2000), and details of the seismic-reflection data acquisition and processing are described by Foster and others (1999).

The area offshore of Fire Island was resurveyed in May 2011 aboard the motor vessel Scarlett Isabella by using an interferometric sonar to acquire bathymetric and backscatter data and a chirp seismic-reflection profiler to define the subsurface stratigraphy and structure. The survey area extends about $50 \mathrm{~km}$ alongshore and about $8 \mathrm{~km}$ offshore in water depths ranging from approximately 8 to 32 meters (m) (fig. 1) and covers approximately 336 square kilometers $\left(\mathrm{km}^{2}\right)$. Details of the acquisition and processing of these data are described in Schwab, Denny, and Baldwin (2014).

Modern sediment thickness mapped in 2011 covered an area of about $274 \mathrm{~km}^{2}$ (Schwab, Denny, and Baldwin, 2014) and was used for comparison to the modern sediment thickness mapped in 1996-97 (Foster and others, 1999). Ship position for both surveys was determined by using a Differential Global Positioning System (DGPS). The layback position of the seismic-reflection system towfish relative to the ship was accounted for in both surveys. We estimate that the positions of the seismic-reflection data are accurate to within $5 \mathrm{~m}$.

The sediment thickness mapped in 1996-97 by Foster and others (1999) was calculated from two-way travel time on seismic-reflection profiles by using an assumed internal velocity of 1,630 meters per second $(\mathrm{m} / \mathrm{s})$. However, the sediment thickness mapped in 2011 by Schwab, Denny, and Baldwin (2014) was calculated from two-way travel time by using an assumed internal velocity of 1,500 m/s. In order to compare the 1996-97 and 2011 datasets, the 1996-97 sediment thickness was converted to the common internal velocity of 1,500 m/s used by Schwab, Denny, and Baldwin (2014) by multiplying by a factor of 0.92 . The two datasets were then compared, yielding a difference grid (fig. 3) with a resolution of 100-m grid cell size to match the coarser input of the 1996-97 data. 
A vertical resolution of 50 centimeters $(\mathrm{cm})$ is assumed for sediment volume calculations because of a conservative estimate of the vertical resolution limits of the subbottom profiling systems used during the 1996-97 and 2011 surveys.

\section{Mapping Results}

Previous interpretations of marine geologic mapping data support the hypothesis that the Holocene evolution of Fire Island, including its modern decadal to centennial behavior, is linked directly to the geologic framework of the inner continental shelf. Schwab, Thieler, Denny, and others (2000) and Schwab and others (2013) identified the modern sediment deposit on the inner continental shelf offshore of Fire Island as a likely source of sediment required to balance the coastal sediment budget, suggesting that an onshore-directed component of the dominant westerly sediment flux (from the inner continental shelf to the shoreface), in combination with periodic contribution from beach nourishment activities, provides sufficient sediment to maintain island stability west of Watch Hill.

A comparison of modern sediment thickness mapped from seismic-reflection data in 1996-97 (Foster and others, 1999; Schwab, Thieler, Allen, and others, 2000) and 2011 (Schwab, Denny, and Baldwin, 2014) provides evidence to support the hypothesis of shoreward-directed sediment flux. The comparison (figs. 3 and 4), which shows changes in sediment thickness greater than $50 \mathrm{~cm}$ (the vertical resolution limit of the subbottom systems used in the two surveys), illustrates net westerly migration of the sand ridges, with erosion on their eastern flanks and crests and deposition on their western flanks, as well as significant accretion along the lower shoreface of western Fire Island.

Schwab, Baldwin, Denny, and others (2014) calculated that the modern sediment volume on the lower shoreface has accreted $7.8 \times 10^{6}$ cubic meters $\left(\mathrm{m}^{3}\right)$ and the modern sand deposit on the inner continental shelf was reduced by $3.1 \times 10^{6} \mathrm{~m}^{3}$ over the 15 -year period. This led them to speculate that the lower shoreface modern sediment deposit has gained volume at the expense of deflation of the large shoreface-attached sand ridges and inner continental shelf in general. This raises a question: if the shoreface-attached sand ridges are eroding, how are these prominent features maintained in the long term?

While attempting to address this question, an error was discovered in the volumetric calculations presented in Schwab, Baldwin, Denny, and others (2014); they did not convert the modern sediment thickness isopach of the 1996-97 survey produced by Foster and others (1999) to the common velocity of $1,500 \mathrm{~m} / \mathrm{s}$ prior to comparing to the 2011 data (Schwab, Denny, and Baldwin, 2014). Although seemingly a minor correction (see "Data Collection and Processing" section above), following conversion the modern sediment volume of the lower shoreface is shown to have increased on the lower shoreface by $10.2 \times 10^{6} \mathrm{~m}^{3}$ and increased on the inner continental shelf by $10.0 \times 10^{6} \mathrm{~m}^{3}$ over the 15 year timespan; total accretion of $20.2 \times 10^{6} \mathrm{~m}^{3}$. This calculation includes the mining of $2.4 \times 10^{6} \mathrm{~m}^{3}$ of sand for beach nourishment activities (Lentz and others, 2013). Thus, speculation by Schwab, Baldwin, Denny, and others (2014) that the lower shoreface has gained volume at the expense of deflation of the shoreface-attached sand ridges is incorrect.

Modern sediment thicknesses greater than $50 \mathrm{~cm}$ were mapped over $112 \mathrm{~km}^{2}$ in the 1996-97 surveys (41 percent of the mapped area) and over $119 \mathrm{~km}^{2}$ of the 2011 survey (43 percent of the mapped area). The mean change in modern sediment thickness for the mapped area is $+0.07 \mathrm{~m}$, with the mean gain in areas of accretion $+0.56 \mathrm{~m}$ and mean loss in areas of erosion $-0.14 \mathrm{~m}$. This strongly implies that erosion of Pleistocene glaciofluvial and lower Holocene channel-fill deposits exposed at the seafloor continues to yield the modern sediment required to balance the coastal sediment budget (Schwab and others, 2013) and maintain the shoreface-attached sand ridges. 


\section{References Cited}

Foster, D.S., Swift, B.A., and Schwab, W.C., 1999, Stratigraphic framework maps of the nearshore area of southern Long Island from Fire Island to Montauk Point, New York: U.S. Geological Survey Open-File Report 99-559, accessed October 2014, at http://pubs.usgs.gov/of/1999/of99-559/.

Leatherman, S.P., and Allen, J.R., 1985, Geomorphic analysis of the south shore barriers of Long Island, New York: Boston, Mass., National Park Service Technical Report, 350 p.

Lentz, E.E., Hapke, C.J., Stockdon, H.F., and Hehre, R.E., 2013, Improving understanding of near-term barrier island evolution through multi-decadal assessment of morphologic change: Marine Geology, $\mathrm{v}$. 337, p. 125-139.

Schwab, W.C., Allison, M.A., Corso, W., Lotto, L.L., Butman, B., Buchholtz ten Brink, M.R., Denny, J.F., Danforth, W.W., and Foster, D.S., 1997, Initial results of high-resolution sea-floor mapping offshore of the New York-New Jersey metropolitan area using sidescan sonar: Northeastern Geology and Environmental Sciences, v. 19, p. 243-262.

Schwab, W.C., Baldwin, W.E., Denny, J.F., Hapke, C.J., Gayes, P.T., List, J.H., and Warner, J.C., 2014, Modification of the Quaternary stratigraphic framework of the inner-continental shelf by Holocene marine transgression-An example offshore of Fire Island, New York: Marine Geology, v. 355, p. 346-360.

Schwab, W.C., Baldwin, W.E., Hapke, C.J., Lentz, E.E., Gayes, P.T., Denny, J.F., List, J.H., and Warner, J.C., 2013, Geologic evidence for onshore sediment transport from the inner-continental shelf_-Fire Island, New York: Journal of Coastal Research, v. 29, no. 3, p. 526-544.

Schwab, W.C., Denny, J.F., and Baldwin, W.E., 2014, Maps showing bathymetry and modern sediment thickness on the inner-continental shelf offshore of Fire Island, New York-Pre-hurricane Sandy:

U.S. Geological Survey Open-File Report 2014-1203, accessed December 2014, at http://pubs.usgs.gov/of/2014/1203/.

Schwab, W.C., Thieler, E.R., Allen, J.R., Foster, D.S., Swift, B.A., and Denny, J.F., 2000, Influence of inner-continental shelf geologic framework on the evolution and behavior of the barrier-island system between Fire Island Inlet and Shinnecock Inlet, Long Island, New York: Journal of Coastal Research, v. 16, p. 408-422.

Schwab, W.C., Thieler, E.R., Denny, J.F., Danforth, W.W., and Hill, J.C., 2000, Seafloor sediment distribution off southern Long Island, New York: U.S. Geological Survey Open-File Report 00-243, accessed October 2014, at http://pubs.usgs.gov/of/2000/of00-243/default.htm.

Stone, B.D., and Borns, H.W., 1986, Pleistocene glacial and interglacial stratigraphy of New England, Long Island and adjacent Georges Bank and Gulf of Maine, in Sibrava, Vladimir, Bowen, D.Q., and Richmond, G.M., eds., Quaternary glaciations in the northern hemisphere: Oxford, Pergamon Press, p. 38-52.

Williams, S.J., 1976, Geomorphology, shallow subbottom structure and sediments of the Atlantic innercontinental shelf off Long Island, New York: Fort Belvoir, Va., U.S. Army Corps of Engineers Technical Paper 76-2, 123 p. 


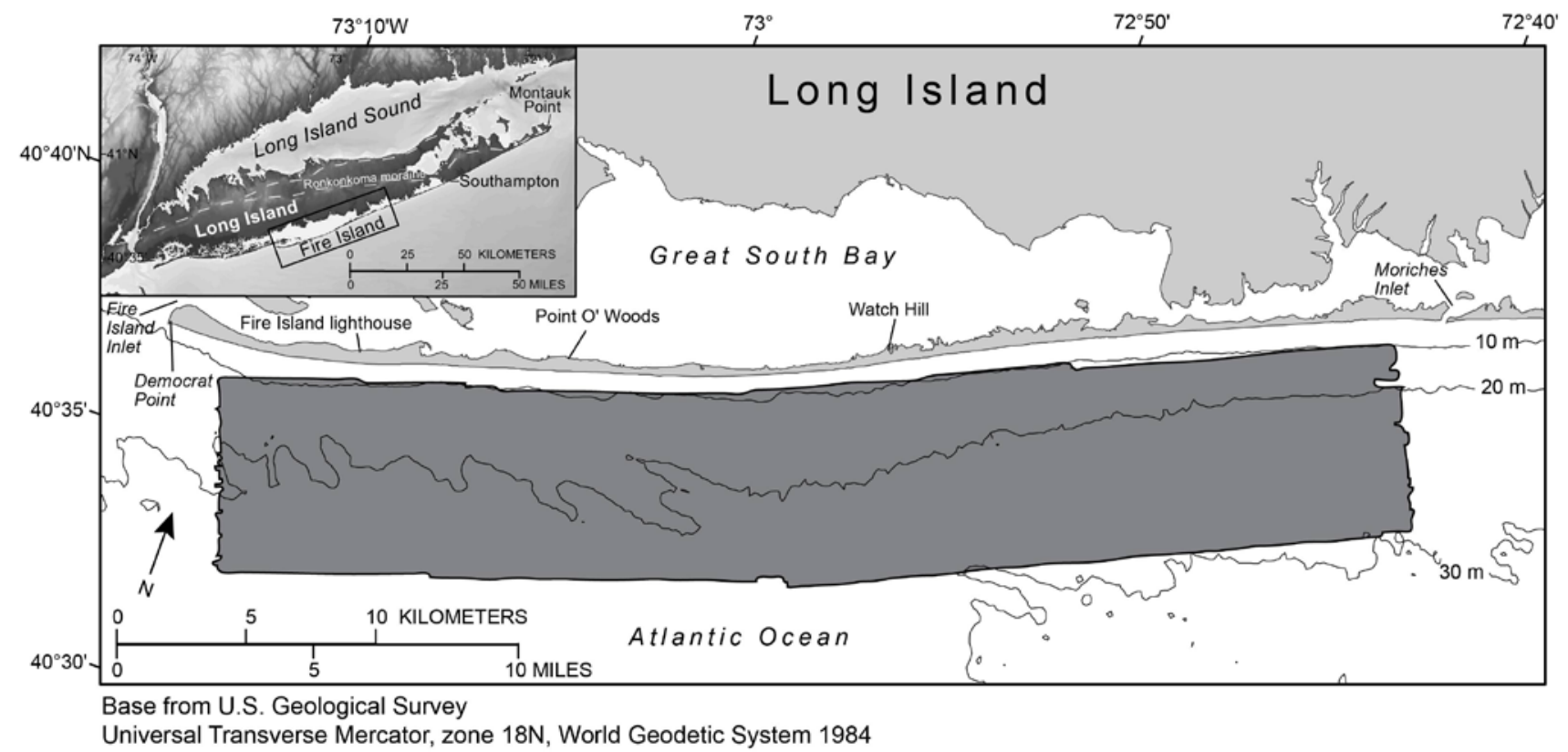

Figure 1. Map showing the survey area (shaded in dark gray) offshore of Fire Island, New York, 2011. Inset map shows location of study area (outlined in black). Bathymetric contours are in meters $(\mathrm{m})$ below the North American Vertical Datum of 1988 (NAVD 88). Figure modified from Schwab and others (2013). 

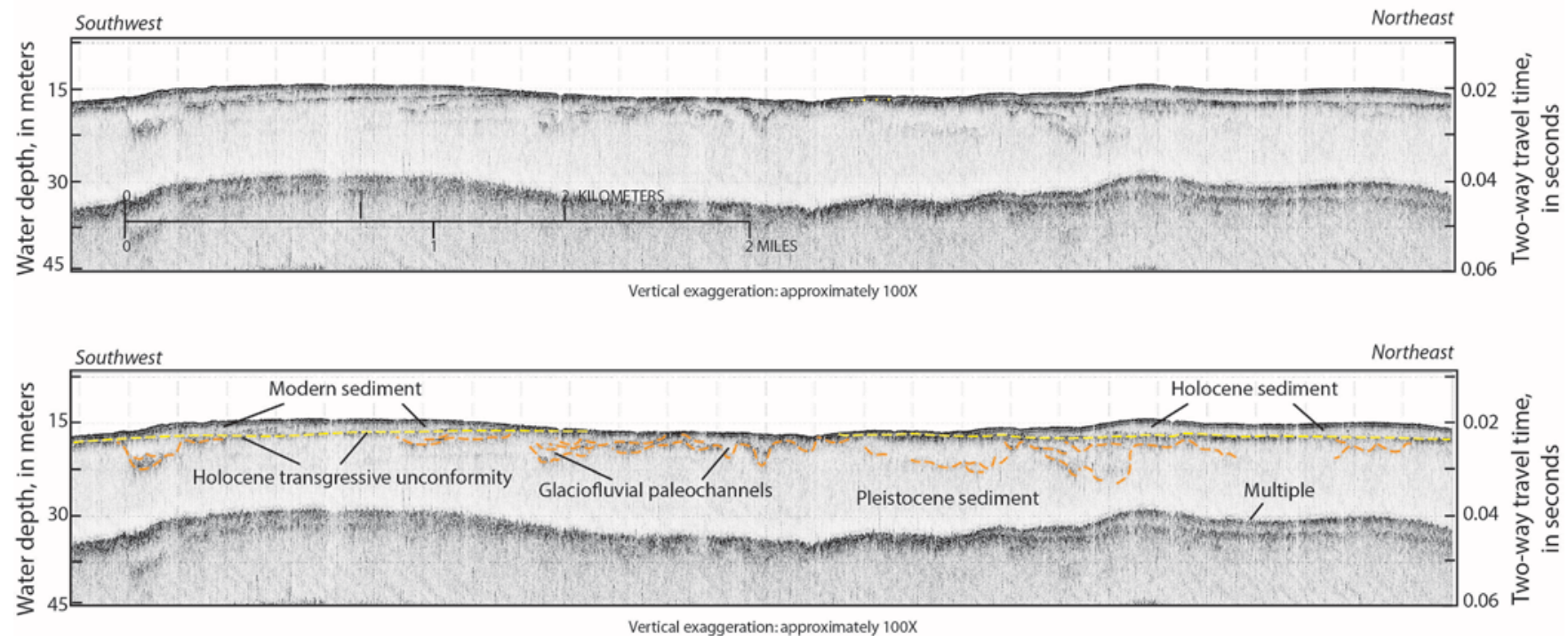

Figure 2. High-resolution chirp seismic-reflection profile and interpretation illustrating stratigraphic features and geometries discussed in the text. Location of the profile is shown in figure 3. Approximate water depth in meters is based on a two-way travel time of 1,500 meters per second. The Holocene transgressive unconformity is marked by a yellow dashed line. Glaciofluvial channels and older Pleistocene sediments are marked by orange dashed lines. Figure modified from Schwab and others (2013). 


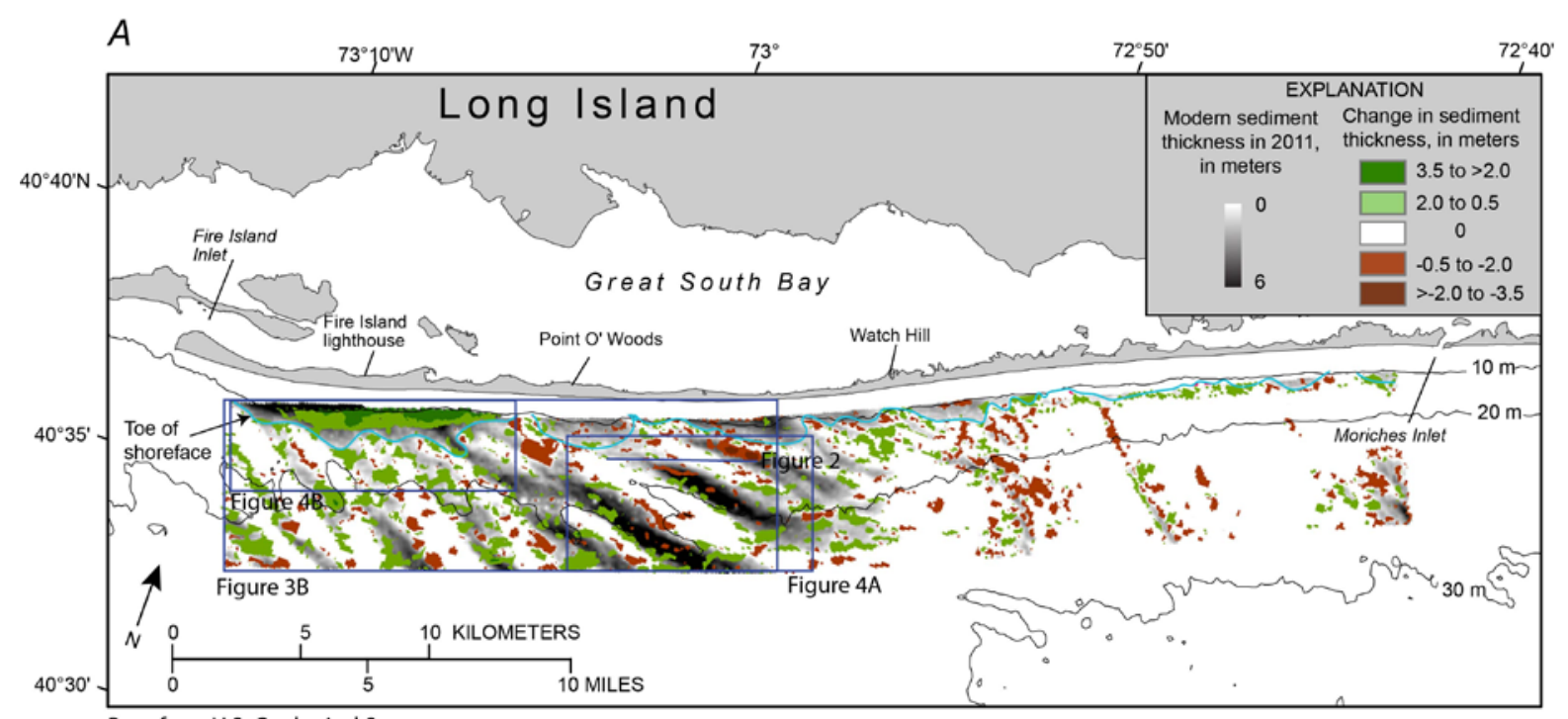

Base from U.S. Geological Survey

Universal Transverse Mercator, zone 18N, World Geodetic System 1984
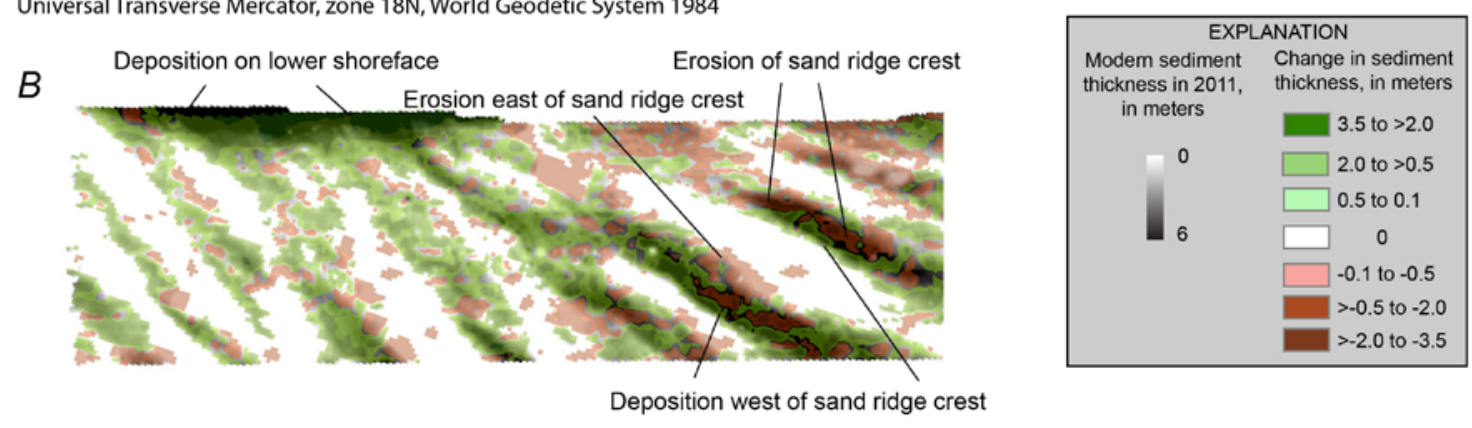

Figure 3. A, Map showing the change in modern sediment thickness greater than 0.5 meter $(\mathrm{m})$ between isopachs interpreted from 1996-97 (Foster and others, 1999) and 2011 (Schwab, Denny, and Baldwin, 2014) seismic-reflection data, overlain on the 2011 modern sediment thickness isopach (Schwab, Denny, and Baldwin, 2014), offshore of Fire Island, New York. Blue line shows seaward extent (toe) of the shoreface (Schwab, Baldwin, Denny, and others, 2014). Regional bathymetric contours are in meters below the North American Vertical Datum of 1988 (NAVD 88). Figure modified from Schwab, Baldwin, Denny, and others (2014). B, Enlargement of area shown in $A$. Change in sediment thickness shown by using a less conservative vertical resolution limit of 10 centimeters to illustrate net westerly migration of the sand ridges, with erosion on the eastern flanks and crests of the ridges and deposition on the western flanks. 


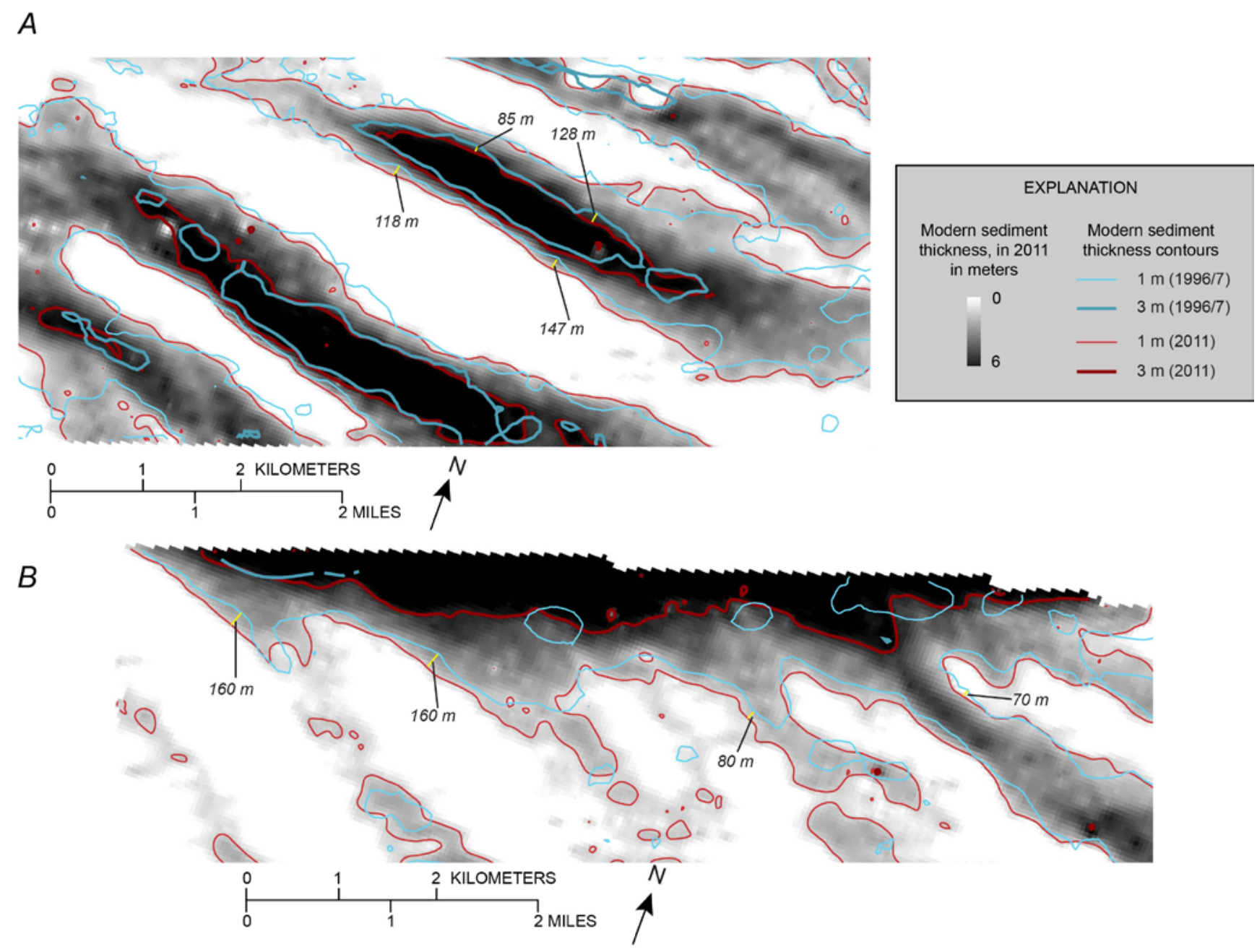

Figure 4. Maps showing the 1- and 3-meter ( $\mathrm{m}$ ) contours of sediment thickness from the 1996-97 and 2011 surveys offshore of Fire Island, New York, of the $A$, shoreface-attached sand ridges and $B$, area of accretion on the lower shoreface overlain on the 2011 modern sand thickness (Schwab, Denny, and Baldwin, 2014). Yellow lines illustrate the southwest migration of contours. See figure $3 A$ for locations. 
Prepared by the Pembroke Publishing Service Center.

For more information concerning this report, contact:

Director

Woods Hole Coastal and Marine Science Center

U.S. Geological Survey

384 Woods Hole Road

Quissett Campus

Woods Hole, MA 02543-1598

WHSC_science_director@usgs.gov

508-548-8700 or 508-457-2200

or visit our Web site at:

http://woodshole.er.usgs.gov/ 
